\title{
Obesity and central obesity in Indonesia: evidence from a national health survey
}

\author{
Dante S. Harbuwono, ${ }^{1,2}$ Laurentius A. Pramono, ${ }^{3}$ Em Yunir, ${ }^{1}$ Imam Subekti ${ }^{1}$ \\ ${ }^{1}$ Department of Internal Medicine, Faculty of Medicine Universitas Indonesia, Jakarta, Indonesia \\ ${ }^{2}$ Indonesian Society for the Study of Obesity (ISSO/HISOBI) \\ ${ }^{3}$ Department of Internal Medicine, St Carolus Hospital, Jakarta, Indonesia
}

\section{ABSTRACT}

Background: Obesity and central obesity have become serious public health problems in developing countries such as Indonesia. Although 10 years have passed since the largest national health survey was conducted in 2007, no further analysis and publication concerning obesity and central obesity in Indonesia have been conducted based on the survey. The aim of this study is to determine the prevalence of obesity and central obesity, and its association with sociodemographic characteristics and comorbidities in Indonesia.

Methods: A cross-sectional study was conducted based on the National Basic Health Survey 2007 using total sampling method from 33 provinces. Obesity is defined as body mass index $\geq 25$ according to the Asia-Pacific standard for obesity. Central obesity is defined as waist circumference $>90 \mathrm{~cm}$ for men and $>80 \mathrm{~cm}$ for women according to the Asia-Pacific standard for central obesity.

Results: The prevalence of obesity and central obesity in the Indonesian adult population are $23.1 \%$ and $28 \%$, respectively. Both rates are higher in females than in males. Obesity and central obesity are associated with the risk of diabetes and hypertension.

Conclusion: Prevalence of obesity and central obesity is high in the Indonesian adult population. Interventional programs are important to promote awareness of obesity and healthy lifestyle changes in the community.

Keywords: central obesity, epidemiology, Indonesia, obesity

pISSN: 0853-1773 • eISSN: 2252-8083 • https://doi.org/10.13181/mji.v27i2.1512 • Med J Indones. 2018;27:114-20

- Received 28 Jul 2016 • Accepted 04 Apr 2018

Corresponding author: Dante S. Harbuwono

danteid@yahoo.com

Copyright @ 2018 Authors. This is an open access article distributed under the terms of the Creative Commons Attribution-NonCommercial 4.0 International License (http://creativecommons.org/licenses/by-nc/4.0/), which permits unrestricted non-commercial use, distribution, and reproduction in any medium, provided the original author and source are properly cited. 
Obesity is projected to become a public health concern worldwide, ${ }^{1}$ and it is becoming a serious problem in developing countries. ${ }^{1,2}$ The World Health Organization (WHO) Expert Consultation on Obesity has warned about the escalation of obesity prevalence in developing countries. A previous WHO report on Diet, Nutrition, and the Prevention of Chronic Diseases mentioned obesity as the main risk factor for all non-communicable diseases. ${ }^{3}$ In Indonesia, obesity and central obesity have become major health issues since the "double burden of disease" has affected the Indonesian population. On the one hand, infection remains a major cause of morbidity and mortality; on the other hand, the incidence of non-communicable diseases such as obesity, diabetes, cardiovascular illness, and cancer is increasing. ${ }^{4}$

Few national surveys have been conducted to reveal the epidemiology of obesity and central obesity in Indonesia. One of the most complete national surveys, which showed the prevalence of obesity, central obesity and other metabolic parameters such as diabetes, hypertension, dietary profile, and sociodemographic characteristics, was the National Basic Health Survey in 2007..$^{5}$ This survey was the most comprehensive national survey conducted in Indonesia in the third millennium.

Although 10 years have passed since the survey, no further analysis and publication based on the survey discuss the epidemiology of obesity and central obesity in the country. The aim of the present study is to determine the prevalence of obesity and central obesity, as well as its association with sociodemographic characteristics and comorbidities in Indonesia. We have also conducted subgroup analysis based on gender to show if gender disparities affect the association of obesity and central obesity with other comorbidities.

\section{METHODS}

\section{Study design}

This is a cross-sectional study based on the National Basic Health Survey conducted in 2007 by the Ministry of Health of the Republic of Indonesia. The survey used simple random sampling from populations of 33 provinces. It was one of the largest national health surveys ever conducted in Indonesia.

\section{Population}

The study population is the adult population (over 18 years old) of Indonesians who live in cities in 33 provinces. We use total sampling method on the biomedical section study population because all samples in this section (whose blood samples are being collected) are used in this study, excluding subjects with incomplete data and defective blood samples.

\section{Interview, physical examination, and laboratory measurement}

All subjects included in the National Basic Health Survey 2007 were interviewed, physically examined, and underwent laboratory examination by enumerators in each district and province. The interview consisted questions on sociodemographic characteristics, structured health records, health-related habits such as dietary profiles and smoking, and health complaints. Physical examination focused on blood pressure and other vital signs, as well as anthropometric measurement such as body mass index and waist circumference. Laboratory examination consisted of hematology, clinical chemistry, and tests for infectious biomarkers such as HIV, hepatitis B, and hepatitis C.

\section{Definitions}

Obesity is defined as body mass index $\geq 25 \mathrm{~kg} / \mathrm{m}^{2}$ according to the Asia-Pacific standard for obesity. ${ }^{6}$ Central obesity is defined as waist circumference $>90 \mathrm{~cm}$ for men and $>80 \mathrm{~cm}$ according to Asia-Pacific standard for central obesity. ${ }^{7}$ Hypertension is defined as having a history of hypertension, taking an antihypertension drug, or having systolic blood pressure $\geq 140 \mathrm{mmHg}$ and/or diastolic blood pressure $\geq 90 \mathrm{mmHg}$. ${ }^{8}$ Based on the definition of the American Diabetes Association, which was adapted by the Indonesian Society of Endocrinology, diabetes is defined as having a history of the disease, taking an anti-diabetes drug, or having blood glucose level $\geq 200 \mathrm{mg} / \mathrm{dL}$ after glucose tolerance test. ${ }^{9}$ For lifestyle related to obesity and other comorbidities, we provide definition adopted from the American College of Sports Medicine and American Heart Association; physical inactivity is defined as a condition where physical activity does not reach 150 minutes 
a week. ${ }^{10}$ Risky dietary habit is defined as low consumption of fruits and vegetables, i.e., less than 5 portions per day in a week. ${ }^{5}$

\section{Statistical analyses}

The data analyses were performed using International Business Machines Statistical Package for the Social Sciences (IBM SPSS) version 17.0. All data were expressed in categorical parameters to divide them closely for the clinical study. Chi square test was performed to find an association between two categorical variables. We did not meet the requirement for the chi square test, and we used the Fischer exact test. All $\mathrm{p}$ values were two-tailed, and statistical significance was defined as $\mathrm{p}<0.05$.

\section{Ethical clearance}

This study was approved by the National Basic Health Survey Committee, Health Research and Development Unit, Ministry of Health of the Republic of Indonesia. The committee also granted us a permission to publish the data.

\section{METHODS}

Subjects were included in the study had a total number of 16,780 . Sociodemographic characteristics are shown in Table 1 . The associations exist between obesity and central obesity with sociodemographic characteristics. Tables 2 and 3 show bivariate analysis of obesity and central obesity with sociodemographic profiles.

According to the bivariate analysis, a significant association exists between all variables of sociodemographic characteristics with obesity and central obesity, except between physical inactivity and central obesity. Tables 4 and 5 show the results of bivariate analysis between obesity and central obesity with hypertension, and of subgroup analysis based on gender disparities. Tables 6 and 7 show the results of bivariate analysis between obesity and central obesity with diabetes, and of subgroup analysis based on gender disparities.

\section{DISCUSSION}

Indonesia is the world's fourth most populous nation and 10th largest economy in terms of purchasing power parity. The country's gross national income per capita had increased from $\$ 560$ in 2000 to $\$ 3650$ in $2014 .{ }^{11}$ Until now, Indonesia is still categorized as a middle-income developing country. According to a systematic review conducted by Dinsa et $\mathrm{al}^{12}$ middle-income

Table 1. Sociodemographic and clinical characteristics of subjects

\begin{tabular}{|c|c|}
\hline Characteristics & n $(\%)$ \\
\hline \multicolumn{2}{|l|}{ Gender } \\
\hline Male & $7788(46.4)$ \\
\hline Female & $9001(53.6)$ \\
\hline \multicolumn{2}{|l|}{ Age (years) } \\
\hline $18-27$ & $5256(31.3)$ \\
\hline $28-37$ & $3964(23.6)$ \\
\hline $38-47$ & $3432(20.4)$ \\
\hline $48-57$ & $2230(13.3)$ \\
\hline$\geq 58$ & 1907 (11.4) \\
\hline \multicolumn{2}{|l|}{ Socioeconomic status } \\
\hline Low & $6554(39)$ \\
\hline High & $10235(61)$ \\
\hline \multicolumn{2}{|l|}{ Educational background } \\
\hline $\begin{array}{l}\text { Basic (up to Junior High } \\
\text { School) }\end{array}$ & $6376(38.2)$ \\
\hline Higher & $10295(61.8)$ \\
\hline \multicolumn{2}{|l|}{ Body mass index } \\
\hline Not obese & $12989(76.9)$ \\
\hline Obese & 3882 (23.1) \\
\hline \multicolumn{2}{|l|}{ Waist circumference } \\
\hline No central obesity & 11902 (72) \\
\hline With central obesity & $4634(28)$ \\
\hline \multicolumn{2}{|l|}{ Blood pressure } \\
\hline No hypertension & $11129(67.3)$ \\
\hline With hypertension & 5407 (32.7) \\
\hline \multicolumn{2}{|l|}{ Blood glucose } \\
\hline No diabetes & $14982(93,5)$ \\
\hline With diabetes & $1058(6,5)$ \\
\hline \multicolumn{2}{|l|}{ Physical activity status } \\
\hline Active & $12264(73)$ \\
\hline Inactive & $4525(27)$ \\
\hline \multicolumn{2}{|l|}{ Dietary profile } \\
\hline Low-risk & $311(1.9)$ \\
\hline High-risk & $16360(98.1)$ \\
\hline \multicolumn{2}{|l|}{ Smoking habit } \\
\hline Smoker & $5109(30.7)$ \\
\hline Past smoker & $728(4.4)$ \\
\hline Not a smoker & $10834(65)$ \\
\hline
\end{tabular}


Table 2. Association between obesity and sociodemographic characteristics

\begin{tabular}{|c|c|c|c|}
\hline & & Obesity, n (\%) & Total, $\mathrm{n}$ \\
\hline \multirow[t]{2}{*}{ Gender } & Male & 1313 (16.9) & 7783 \\
\hline & Female & $2569(28.6)$ & 8997 \\
\hline \multirow[t]{5}{*}{ Age (years) } & $18-27$ & 507 (9.7) & 5248 \\
\hline & $28-37$ & $1098(27.7)$ & 3964 \\
\hline & $38-47$ & $1146(33.4)$ & 3431 \\
\hline & $48-57$ & 731 (32.8) & 2230 \\
\hline & $\geq 58$ & $400(21)$ & 1907 \\
\hline \multirow[t]{2}{*}{ Socioeconomic* } & High & 2553 (25) & 10226 \\
\hline & Low & $1329(20.3)$ & 6554 \\
\hline \multirow[t]{2}{*}{ Dietary profiles $^{\dagger}$} & $\begin{array}{l}\text { Low } \\
\text { risk }\end{array}$ & 3779 (23.1) & 16358 \\
\hline & $\begin{array}{l}\text { High } \\
\text { risk }\end{array}$ & $96(30.9)$ & 311 \\
\hline \multirow[t]{2}{*}{ Physical activity } & Active & 3055 (24.1) & 12651 \\
\hline & Inactive & $827(20)$ & 4129 \\
\hline \multirow[t]{2}{*}{$\begin{array}{l}\text { Educational } \\
\text { background }^{\dagger}\end{array}$} & Basic & $1579(24.8)$ & 6376 \\
\hline & Higher & $2296(22.3)$ & 10293 \\
\hline
\end{tabular}

All variables have $\mathrm{p}<0.001 ;{ }^{\dagger}$ missing data $(\mathrm{n}=104 ; 0.6 \%)$; ${ }^{ \pm}$missing data ( $\left.\mathrm{n}=111 ; 0.66 \%\right)$

countries have a mixed pattern of socioeconomic inequalities in obesity. In Indonesia, obesity and central obesity are more often observed in people with high socioeconomic level than those with low socioeconomic level. Moreover, a significant association is found between socioeconomic level and obesity and central obesity. This association is stronger in women than in men. ${ }^{12}$

The double burden of malnutrition occurs mostly in developing countries all over the world. This condition is characterized by undernutrition among poor children and obesity among many adults. ${ }^{13}$ Prevalence of undernutrition in Indonesian children below five years old varies from year to year. It was $18.4 \%$ in $2007,17.9 \%$ in 2010 , and increased to $19.6 \%$ in 2013 (the highest in 5 years retrospectively). ${ }^{14}$ This is a serious problem given that the prevalence of obesity and central obesity in Indonesia are $23.1 \%$ and $28 \%$, respectively. Unfortunately, no survey has been conducted to determine obesity and central obesity prevalence nationwide after the national basic survey in 2007.
Table 3. Association between central obesity and sociodemographic characteristics

\begin{tabular}{|c|c|c|c|}
\hline & & $\begin{array}{c}\text { Central obese, } \\
n(\%)\end{array}$ & $\begin{array}{c}\text { Total, } \\
\mathrm{n}\end{array}$ \\
\hline \multirow[t]{2}{*}{ Gender } & Male & $924(12.1)$ & 7667 \\
\hline & Female & $3710(41.9)$ & 8869 \\
\hline \multirow[t]{5}{*}{ Age } & $18-27$ & 789 (15.8) & 5003 \\
\hline & $28-37$ & 1150 (29) & 3964 \\
\hline & $38-47$ & $1219(35.5)$ & 3432 \\
\hline & $48-57$ & 837 (37.5) & 2230 \\
\hline & $\geq 58$ & $639(33.5)$ & 1907 \\
\hline \multirow[t]{2}{*}{ Socioeconomic } & High & 2991 (29.7) & 10079 \\
\hline & Low & $1643(25.4)$ & 6457 \\
\hline \multirow[t]{2}{*}{ Dietary profiles* } & $\begin{array}{l}\text { Low } \\
\text { risk }\end{array}$ & 4524 (27.9) & 16228 \\
\hline & $\begin{array}{l}\text { High } \\
\text { risk }\end{array}$ & $110(25.7)$ & 308 \\
\hline \multirow[t]{2}{*}{ Physical activity $^{\dagger}$} & Active & 3548 (28.2) & 12587 \\
\hline & Inactive & $1086(27.5)$ & 3949 \\
\hline \multirow[t]{2}{*}{$\begin{array}{l}\text { Educational } \\
\text { background }^{\ddagger, \S}\end{array}$} & Basic & $1710(26.8)$ & 6375 \\
\hline & Higher & 2924 (28.8) & 10161 \\
\hline
\end{tabular}

${ }^{*} \mathrm{p}<0.01 ;{ }^{\dagger} \mathrm{p}<0.207 ;{ }^{\ddagger} \mathrm{p}<0.003 ;{ }^{\S} \mathrm{missing}$ data $(\mathrm{n}=244 ; 1.45 \%)$

Undernutrition causes an insufficient immunity to fight the infections and is correlated with a low intelligence and productivity. Similar to diabetes, hypertension, and metabolic syndrome, obesity is considered as a risk factor for other serious health outcomes such as stroke, cardiovascular disease, cancer, disability, and death. The obesity epidemic is related to gender, age, socioeconomic level, educational background, and ethnicity. ${ }^{15}$ The association is dynamic based on many aspects. Gender disparities are one of the most complex issues in discussing the epidemiology of obesity and central obesity, especially in developing countries. ${ }^{16}$ Many factors contribute to the association, such as daily diet, lifestyle, urbanization, nutrition transition, occupation, and role in society. ${ }^{16}$

According to the national survey, the prevalence of obesity in Indonesia is $23.1 \%$, which is lower than the $28 \%$ rate of central obesity. A significant difference exists between the percentage of males and females who have obesity and central obesity. The percentages of obese males and females are $16.9 \%$ and $28.6 \%$, 
respectively, while for central obesity, the percentages are $12.1 \%$ and $41.9 \%$, respectively. These results represent a major finding in epidemiology. They show that in the Indonesian population, females have a higher risk of metabolic syndrome than males. This finding varies depending on the age group and population study. Al-Hazzaa et $\mathrm{al}^{17}$ in Saudi Arabia showed that teenage obesity and central obesity are more prevalent in males than in females. Wang et $\mathrm{al}^{18}$ on the adult Chinese population found that obesity is more frequent in males than in females (15.7\% versus $14.3 \%$ ), but central obesity is more frequent in females than in males $(43.9 \%$ versus $31.1 \%)$.

The association between obesity and central obesity with sociodemographic characteristics varies. Some variables, such as a dietaryprofileand physicalactivity, have an inverse association with obesity and central obesity. This phenomenon shows how epidemiological findings do not always match rational and clinical

Table 4. Association between hypertension as well as diabetes and obesity

\begin{tabular}{|c|c|c|c|c|c|}
\hline & & \multicolumn{2}{|c|}{ Hypertension } & \multicolumn{2}{|c|}{ Diabetes } \\
\hline & & $\begin{array}{c}\mathrm{n} \\
(\%)\end{array}$ & Total & $\begin{array}{c}\mathrm{n} \\
(\%)\end{array}$ & Total \\
\hline \multirow[t]{3}{*}{ Obesity } & Yes & $\begin{array}{c}1869 \\
(48.3)\end{array}$ & 3869 & $\begin{array}{c}539 \\
(12.3)\end{array}$ & 3660 \\
\hline & No & $\begin{array}{c}3568 \\
(28.2)\end{array}$ & 12666 & $\begin{array}{c}514 \\
(4.4)\end{array}$ & 12380 \\
\hline & Total & $\begin{array}{c}5407 \\
(32.7)\end{array}$ & $16535^{*}$ & $\begin{array}{l}1053 \\
(6.5)\end{array}$ & $16040^{+}$ \\
\hline \multirow[t]{3}{*}{$\begin{array}{l}\text { Obesity } \\
\text { (Male) }\end{array}$} & Yes & $\begin{array}{c}683 \\
(52.1)\end{array}$ & 1310 & $\begin{array}{c}127 \\
(11.5)\end{array}$ & 1537 \\
\hline & No & $\begin{array}{c}1797 \\
(28.3)\end{array}$ & 6356 & $\begin{array}{l}297 \\
(4)\end{array}$ & 7094 \\
\hline & Total & $\begin{array}{l}2480 \\
(32.4)\end{array}$ & 7666 & $\begin{array}{l}424 \\
(5)\end{array}$ & 8631 \\
\hline \multirow[t]{3}{*}{$\begin{array}{l}\text { Obesity } \\
\text { (Female) }\end{array}$} & Yes & $\begin{array}{c}1186 \\
(46.3)\end{array}$ & 2559 & $\begin{array}{c}413 \\
(9.3)\end{array}$ & 3096 \\
\hline & No & $\begin{array}{l}1741 \\
(27.6)\end{array}$ & 6310 & $\begin{array}{c}219 \\
(3.8)\end{array}$ & 7218 \\
\hline & Total & $\begin{array}{l}2927 \\
(33)\end{array}$ & 8869 & $\begin{array}{c}632 \\
(6.2)\end{array}$ & 10314 \\
\hline
\end{tabular}

All variables have $\mathrm{p}<0.001 ;{ }^{*}$ missing data $(\mathrm{n}=245 ; 1.4 \%)$; ${ }^{\dagger}$ missing data $(\mathrm{n}=740 ; 4.4 \%)$ theories. People with high socioeconomic status have a higher risk of being obese and central obese than those with low socioeconomic status. However, in terms of education background, the association is inverse between obesity and central obesity. Socioeconomic status and educational background have long been complex yet unpredicted risk factors for obesity and central obesity, as shown in many studies. ${ }^{19}$ In developed countries, obesity has been shown to be inversely associated with socioeconomic status but it is less predictablein developing countries. ${ }^{20}$ In Indonesia, the distribution of obesity and central obesity in a population with diverse socioeconomic and educational backgrounds makes the association only a coincidental findings.

Other important concerns in the epidemiological study of non-communicable diseases is the risk of having comorbidities. In the case of obesity and central obesity, the

Table 5. Association between hypertension as well as diabetes and central obesity

\begin{tabular}{|c|c|c|c|c|c|}
\hline & & \multicolumn{2}{|c|}{ Hypertension } & \multicolumn{2}{|c|}{ Diabetes } \\
\hline & & $\begin{array}{c}n \\
(\%)\end{array}$ & Total & $\begin{array}{c}n \\
(\%)\end{array}$ & Total \\
\hline \multirow[t]{3}{*}{$\begin{array}{l}\text { Central } \\
\text { Obesity }\end{array}$} & Yes & $\begin{array}{c}2104 \\
(45.4)\end{array}$ & 4634 & $\begin{array}{c}539 \\
(12.3)\end{array}$ & 4394 \\
\hline & No & $\begin{array}{c}3303 \\
(27.8)\end{array}$ & 11902 & $\begin{array}{c}514 \\
(4.4)\end{array}$ & 11646 \\
\hline & Total & $\begin{array}{c}5407 \\
(32.7)\end{array}$ & $16536^{*}$ & $\begin{array}{l}1053 \\
(6.5)\end{array}$ & $16040^{\dagger}$ \\
\hline \multirow[t]{3}{*}{$\begin{array}{l}\text { Central } \\
\text { Obesity } \\
\text { (Male) }\end{array}$} & Yes & $\begin{array}{c}482 \\
(52.2)\end{array}$ & 924 & $\begin{array}{c}127 \\
(11.5)\end{array}$ & 1108 \\
\hline & No & $\begin{array}{c}1998 \\
(29.6)\end{array}$ & 6743 & $\begin{array}{l}297 \\
(4)\end{array}$ & 7399 \\
\hline & Total & $\begin{array}{c}2480 \\
(32.3)\end{array}$ & 7667 & $\begin{array}{l}424 \\
(5)\end{array}$ & 8507 \\
\hline \multirow{3}{*}{$\begin{array}{l}\text { Central } \\
\text { Obesity } \\
\text { (Female) }\end{array}$} & Yes & $\begin{array}{c}1622 \\
(43.7)\end{array}$ & 3710 & $\begin{array}{c}413 \\
(9.3)\end{array}$ & 4438 \\
\hline & No & $\begin{array}{c}1305 \\
(25.3)\end{array}$ & 5159 & $\begin{array}{c}219 \\
(3.8)\end{array}$ & 5735 \\
\hline & Total & $\begin{array}{l}2927 \\
(33)\end{array}$ & 8869 & $\begin{array}{c}632 \\
(6.2)\end{array}$ & 10173 \\
\hline
\end{tabular}

All variables have $\mathrm{p}<0.001$; *missing data $(\mathrm{n}=244 ; 1.4 \%)$; ${ }^{\dagger}$ missing data $(\mathrm{n}=740 ; 4.4 \%)$ 
comorbidities are diabetes, hypertension, dyslipidemia, and metabolic syndrome. In many clinical studies, the endpoint of obesity, central obesity, diabetes, and hypertension are cardiovascular events, which are not assessed in the present study because the survey did not obtain electrocardiograph data and other cardiovascular parameters. In this study, obesity and central obesity are strongly associated with hypertension and diabetes $(\mathrm{p}<0.001)$.

Subgroup analysis based on gender also revealed no difference between males and females in the association between obesity and central obesity and the risk of having hypertension and diabetes. The role of gender disparities in the association also varies between study populations. In the Chinese population, males with central obesity tend to have metabolic syndrome and its components (including diabetes and hypertension) compared with females with central obesity. ${ }^{21}$ However, Naser et $\mathrm{al}^{22}$ stated from evidence that central obesity is a strong risk factor for having type 2 diabetes irrespective of age, gender, and ethnicity. Central obesity is also an independent risk for cardiovascular disease irrespective of gender. $^{22}$

The fact that obesity and central obesity are strongly associated with hypertension and diabetes, according to the nationwide epidemiological study, prompts public health agencies to initiate large-scale community intervention programs to reduce these health problems. The program should involve many stakeholders such as government and local administrations, the Ministry of Health, medical doctors, nurses, dieticians, and pharmacists. The program should focus on increasing health promotion as well as encouraging physical activity, healthy lifestyle, healthy food and diet, and education at the elementary and high school levels.

Many success stories about community programs in developing countries have been reported, such as in India and China, to encourage society through government policy which increases public awareness of obesity, central obesity, metabolic syndrome, diabetes, and cardiovascular disease. ${ }^{23}$ The intervention program from school age has been proven to have benefits regarding health such as early identification of the health risk of being obese or central obese and providing input to social, psychological, cultural, as well as traditions of healthy lifestyle. ${ }^{24}$ In many developed countries, public health responsibility is dominated by health promotion and prevention instead of diagnosis and therapy. This paradigm, which requires action, remains a major challenge for the Ministry of Health and the health sector in each province and district. At present, the Indonesian government is facing the challenge of local autonomy.

In conclusion, the prevalence of obesity and central obesity are two important modifiable risk factors for many non-communicable diseases, in the Indonesian adult population are $23.1 \%$ and $28 \%$, respectively. The prevalence of both is higher in females than in males. Obesity and central obesity are associated with many sociodemographic characteristics such as age, gender, socioeconomic status, and educational background. It is also associated with the risk of having diabetes and hypertension. Community programs in the public health setting are crucial to promote awareness of obesity and central obesity. Thus, such programs should focus on encouraging lifestyle changes to prevent health problems.

\section{Acknowledgment}

We thank Trihono, MD, PhD; Prof. Agus Purwadianto, MD, PhD; and Prof. Tjandra Yoga Aditama, MD from the Health Research and Development Unit, Ministry of Health of the Republic of Indonesia for providing data on the Basic National Health Survey used in this study. We are also grateful to the Division of Metabolic Endocrinology, Department of Internal Medicine, Faculty of Medicine of Universitas Indonesia for supporting our work.

\section{Conflict of interest}

Laurentius A. Pramono is one of the editorial board members, but was not involved in the review or decision process of the article. The authors declare that this work is an epidemiological study using secondary data from the Health Research and Development Unit, Ministry of Health, Republic of Indonesia. No funding from any pharmaceutical company has been granted to the researchers. 


\section{REFERENCES}

1. Ellulu M, Abed Y, Rahmat A, Ranneh Y, Ali F. Epidemiology of obesity in developing countries: challenges and prevention. Glob Epidemi Obes. 2014;2(2):1-6.

2. Cecchini M. Obesity Update. The Organization for Economic Co-operation and Development (OECD), 2014.

3. Prentice AM. The emerging epidemic of obesity in developing countries. Int J Epidemiol. 2006;35(1):93-9.

4. Mihardja L, Soetrisno U. Prevalence and determinant factors for overweight and obesity and degenerative diseases among young adults in Indonesia. JAFES. 2012;27(1):77-81.

5. Health Research and Development Unit. National Basic Health Survey 2007. Ministry of Health Republic of Indonesia, 2008.

6. Kanazawa M, Yoshiike N, Osaka T, Numba Y, Zimmet P, Inoue S. Criteria and classification of obesity in Japan and Asia-Oceania. World Rev Nutr Diet 2005;94:1-12.

7. McNeely MJ, Boyko EJ, Shofer JB, Newell-Morris L, Leonetti DL, Fujimoto WY. Standard definitions of overweight and central adiposity for determining diabetes risk in Japanese Americans. Am J Clin Nutr 2001;74(1):101-7.

8. Chobanian AV, Bakris GL, Black HR, Cushman WC, Green LA, Izzo JL, et al. The seventh report of the Joint National Committee on Prevention, Detection, Evaluation, and Treatment of High Blood Pressure. JAMA. 2003;289(19):2560-72.

9. Adi S, Novida H, Rudijanto A, Soewondo P, Suastika K, Manaf A, et al. Consensus on the management of type 2 diabetes in Indonesia. Jakarta: Indonesian Society of Endocrinology; 2015.

10. American College of Sports Medicine and American Heart Association. Recommended amount of physical activity. ACSM/AHA, 2007.

11. World Bank Report. Indonesia Overview. The World Bank, 2015.

12. Dinsa GD, Goryakin Y, Fumagalli E, Suhrcke M. Obesity and socioeconomic status in developing countries: a systematic review. Obes Rev. 2012;13(11):1067-79.

13. Kolčić I. Double burden of malnutrition: a silent driver of double burden of disease in low- and middle-income countries. J Glob Health. 2012;2(2):1-6.

14. Health Research and Development Unit. National Basic Health Survey 2013. Ministry of Health Republic of Indonesia, 2014.

15. Wang Y, Beydoun MA. The obesity epidemic in the United States-gender, age, socioeconomic, racial/ ethnic, and geographic characteristics: a systematic review and meta-regression analysis. Epidemiol Rev. 2007;29(1):6-28.

16. Kanter R, Caballero B. Global gender disparities in obesity: a review. Adv Nutr. 2012;3(4):491-8.

17. Al-Hazzaa HM, Abahussain NA, Al-Sobayel HI, Qahwaji DM, Alsulaiman NA, Musaiger AO. Prevalence of overweight, obesity, and abdominal obesity among Urban Saudi adolescents: gender and regional variations. J Health Popul Nutr. 2014;32(4):634-45.

18. Wang H, Wang J, Liu MM, Wang D, Liu YQ, Zhao Y, et al. Epidemiology of general obesity, abdominal obesity and related risk factors in urban adults from 33 communities of northeast China: the CHPSNE study. BMC Public Health. 2012;12:967.

19. Aitsi-Selmi A, Chen R, Shipley MJ, Marmot MG. Education is associated with lower levels of abdominal obesity in women with a non-agricultural occupation: an interaction study using China's four provinces survey. BMC Public Health. 2013;13:769.

20. Pikhart H, Bobak M, Malyutina S, Pajak A, Kubínová R, Marmot M. Obesity and education in three countries of the central and eastern Europe: the Hapiee study. Cent Eur J Public Health. 2007;15(4):140-2.

21. Xu S, Gao B, Xing Y, Ming J, Bao J, Zhang Q, et al. Gender differences in the prevalence and development of metabolic syndrome in Chinese population with abdominal obesity. PLoS One. 2013;8(10):e78270.

22. Naser KA, Gruber A, Thomson GA. The emerging pandemic of obesity and diabetes: are we going enough to prevent a disaster? Int J Clin Pract. 2006;60(9):1093-7.

23. Misra A, Khurana L. Obesity and the metabolic syndrome in developing countries. J Clin Endocrinol Metab. 2008;93(11 Suppl 1):S9-30.

24. Teixeira E. The effectiveness of community-based programs for obesity prevention and control. Patient Intell. 2011;3:63-72. 